\title{
How is the Practicality of Technopreneurship Scientific Learning Model Design in Vocational Higher Education?
}

\author{
Hendra Hidayat*, ${ }^{*}$, Susi Herawati ${ }^{2}$, Khairul $^{3}$, Boy Yendra Tamin ${ }^{4}$, Eril Syahmaidi ${ }^{5}$ \\ 1,2,3,4,5 Universitas Bung Hatta, Padang, 25133, Indonesia
}

\begin{abstract}
:
This research is aimed to produce a design of learning model in the form of a practical technopreneurship scientific learning model for learning in higher education of vocational education and training. Type of the research is research and development. It was limited to, identify that technopreneurship scientific learning model is practical, and then the product was tested with users; lecturers and students. The questionnaire for assessing the practicality consisted of level of practicality sheet for the users. This instrument was made by using linkert measuring scale. The practicality sheet covered lecturer and students perception towards technopreneurship scientific learning model. It can be practical if it meets the criteria of aspect which is tested to the lecturer to identify attractiveness aspect, aspects of the development process, aspect of user practicality, aspect of functionality and usability, and the aspect of reliability. The result of the research shows that technopreneurship scientific learning model is practical from the lecturer's view. Besides, from the students' view, by identifying the students' interest, the process of its use, improving students activeness in learning process, the product is also practical. These research findings prove that technopreneurship scientific learning model is practical and be able to be used in higher education, especially in practice courses which expect the students to produce a good product in the form of prototype, blueprint, and concept. This technopreneurship scientific learning model can be developed and used in different courses based on the learning needs.
\end{abstract}

Keywords: Practicality, Technopreneurship scientific learning, Vocational higher education.

\section{Introduction}

Vocational education is required to produce a competent workforce in order to increase productivity and efficiency as well as the readiness of the international labor market competition in the era of globalization. For the achievement of the learning process as stipulated in the Law of the Republic of Indonesia Number 20 Year 2003 and Government Regulation No. 32 of 2013, the necessary components of learning that can support the learning process. One of the components of learning is learning model that corresponds to the standards which support education in order to be able to be effective and efficient.

The learning model is one component of which is the primary and essential in supporting the learning process. Therefore, it is necessary to improve the utilization and management so that the desired objectives can be achieved. The model is a description of a reflection of reality that will be done, such as the definition of a model. According to [16] "models by definition are a reflection of reality-temporary stand-ins for something more specific and real; models are helpful in explaining that may be difficult, to describe; may illustrate a model of a process; A models may be a representation of something ".

[26] termed as a model of working procedure that regularly and systematically containing thoughts, description or explanation of a concept. [27] interpret the interaction process of learning as educators with learners to encourage them to learn actively, participatory, interactive with the use of methods, approaches, tools / media, and an appropriate learning environment. [25] defines learning as a basic process of adding information and new capabilities.

The above explanation can be understood that learning model is a procedure or steps that need to be done by educators to facilitate learners to learn actively, participatory and interactively, with the intention of meeting of the educational goals, namely the development of the potential for self- 
learners optimally. With the creation of a good learning model is expected to have an impact on the learning process that goes well too in accordance with the Standards of Content, Process, Assessment and Competency Graduates to be achieved.

Standards of National Education, in [21], are explained that: "Graduates Competency Standards are the criteria regarding the qualifications of graduates' capabilities that include attitudes, knowledge and skills". This article emphasizes that every student should have the attitude and the mastery of knowledge and skills in order to achieve the learning objectives.

[21] also describes the content standards, explained that: "Content Standards are the criteria concerning the scope of material and level of competence to achieve competency of graduates at the level and type of education". This article emphasizes that every graduate of higher education must be in accordance with a predetermined curriculum.

Moreover, [21] describes a standard process that explains that the minimum criteria of student interaction with lecturer and learning resources in the learning environment, resulting in the development of knowledge, skills enhancement, and the formation of attitudes to meet the learning outcomes. This article emphasizes that the interaction between students and lecturers and learning resources should be conducive, so that later can achieve the learning objectives.

As the complement of the above three principles, [21] describes the assessment standards contained in article 24, paragraph 1 . The article explains that the minimum criteria of systematic activities are carried out to determine the qualification of planning and execution, and control of the learning process, as well as after learning achievements of students through the process of learning.

In fact, the learning process is still far from the principles that have been described in [30] and [21]. Even though, vocational education is required to produce a competent workforce in order to increase productivity and efficiency and readiness for competition in the international labor market in the era of globalization. However, based on the data owned by the Central Statistics Agency open unemployment rate in February 2016 amounted to $5.50 \%$. This means that of the 100 workforce, there are about 5-6 people unemployed. "When compared with the condition in February 2015, open unemployment has decreased by $0.31 \%$. Open unemployment is filled by graduates from the
College of both the Diploma and Bachelor These data expose the weakness of college graduates in the competitive labor market, this is due to the learning process that occurs during this time is still oriented to the output instead of outcomes.

This is no exception of the implementation of the learning process carried out vocational higher education which still produces output from each membership but have not touched the aspect of outcomes. Likewise, the practice of learning in vocational education has not been seriously developed based on the principles that have been described to give students the opportunity to learn intelligent, critical, creative, innovative, and problem solving. As we have seen the development of science and technology is developing very fast. Therefore, it should be anticipated by lecturers and students in preparing graduates who are competent. One area of study that is developing very rapidly is a series of power electronics associated with the tools electronics which are consumed by society nowadays. Since it is concerned with the mastery of competencies in the subject of the practice of power electronics circuits required an innovative learning system to provide additional value for students.

Currently the process of learning of power electronics circuits' practices made in the electrical engineering industry in vocational higher education is not succeeding in making students employable and independent, but still in level of ready trained. Practical learning on subjects of Networks Power Electronics at the Department of Electrical Engineering Industry has not shown as a process of development of student creativity.

In the process of learning applied is seen that the learning model is not oriented to the skills in the world of work. Based on observations of the author, almost all of the learning processes executed in conventional methods, where the students come, give the tools and materials, assembling circuit and testing circuit, and the results assessed based on observation. In this case there is rarely an assessment of the student's understanding of what they do. From interviews with several students who are following the practice of Power Electronics Networks revealed that there is little time provided by lecturers to explain what to do and how to do it. As a result, students often do not coherently working order, and sometimes can damage its components.

Based on the findings at the time of observation as described above, there are some problems and phenomena related to the education and training provided to students (especially in Practice Series of 
Power Electronics) is not in accordance with the needs of skills / competencies and skills that they will face in the world of work later. It is necessary for studies of depth, namely in the form of research. Based on the research findings was found later defined strategy improvement for the future. So we need one alternative to development of Technopreneurship scientific learning model. this model in the stage of its implementation is an part of active learning in which learners are given the opportunity to develop the potential, skills and creativity in the learning process of practices. The technopreneurship scientific learning model is a new development of learning model that is expected to be an alternative solution to the implementation of the process of learning the practice of Power Electronics circuit. In essence, the technopreneurship scientific learning model gives learners the opportunity to develop and direct the learners through the steps which are structured in the learning process.

Technopreneurship scientific learning model development on vocational education is in line with the opinion [25] "Vocational technical education can be defined as an educational training which encompasses knowledge, skills, competencies, structural activities, abilities, capabilities and all other structural experiences acquired through formal, on-the-job or off-the job the which is capable of enhancing recipients opportunity for securing jobs in various sectors of the economy or even enabling the person to be self-dependent by being a job creator ", from this quotation, vocational education can be defined as the educational training that includes knowledge, skills, competencies, activities of structural, ability and all the experience of other structural gained through formal, at work or not, which may increase the chance acceptance of jobs in various sectors of the economy or even allow people to be independently to be a job creator. The series of these activities should be designed in a learning stage to support the creation of experience and skills even able to open their own jobs. Of course, the technopreneurship scientific learning model in line with the concept of vocational education.

The technopreneurship scientific learning model that will be developed in outline, its implementation of the learning process which learners together with educators define and agree on what the product will be made jointly both educators and learners with reference to the basic concepts of power electronics circuits' lab materials. Then the students were asked to make an important question about a product, a variety of questions concerning the next product to be mapped questions aimed to see the need and urgency to manufacture products that will be done by students. Furthermore, the students conduct a needs analysis tools and materials of the product to be made and agree a timetable for the manufacture until the finishing product.

This study aims to produce a draft model of learning in the form of technopreneurship scientific learning model that is practical for learning in Technology and Vocational Education of Higher Education.

\section{Research Methods}

The development of research aims to develop a technopreneurship scientific learning model in the form of a valid product, practical and effective. This study is limited to see whether the technopreneurship scientific learning model is practical. Learning conditions are analyzed to identify the weaknesses of learning. This study uses research and development $(\mathrm{RnD})$. This research includes research that develops and produces technopreneurship scientific learning model.

Phase studies of technopreneurship scientific

learning model simplified, include activities namely: a preliminary analysis, design, evaluation and revision [18].

\section{Development Procedures}

\section{Preliminary Analysis}

Needs analysis is the first step in development research. At this stage the researchers analyzed the subject matter to be developed in a technopreneurship scientific learning model that corresponds to essentially competence, analyze the characteristics of students, which include background capabilities, and analyze the ability of lecturers to address learning problems in Educational Technology \& Vocational of Higher Education.

\section{Designing}

Technopreneurship scientific learning model which was developed tailored to subjects where research is in practical power electronics circuit. Steps to be done are to determine the main concepts contained in power electronics circuits. The concept was developed in a way that is easy to understand by the students

\section{Evaluation/Revision}

At this stage, the products that have been made will be evaluated, by testing it to all users (lecturers and students) in small and large groups. Suggestions and comments from users is used to revise the draft model of learning 


\section{Practicality Phase}

The practicalities are level of usable technopreneurship scientific learning model in the learning activities, namely carrying out the teaching experiment by using technopreneurship scientific learning model has been revised based on user ratings. The Technopreneurship scientific learning model has a high practicalities when practical which means easy to use, easy examination and complete with clear instructions. This phase is performed limited testing on electrical engineering students in vocational higher education. To determine the practicalities of the technopreneurship scientific learning model, researchers used a practicality questionnaire sheet.

\section{Research Instrumentation}

The research instruments were developed to collect data in this study is the practicality questionnaire sheet of the technopreneurship scientific learning model by lecturers and students. [29] defines questionnaire as a list of questions or statements that must be filled by the respondents to be evaluated. These practicalities questionnaires were filled by the user, namely lecturer and students.

For students from practicality questionnaire was seen the interest of students, the process of use, increasing the activity of students and a student in learning the practice course power electronics circuits. As for lecturers aspect are viewed aspects of attracting, developing a process aspect, the aspect of ease of use, functionality and usability aspect and the aspect of reliability.

\section{Techniques of Data Analysis}

Techniques of data analysis used were descriptive data analysis techniques, by describing the practicality of using technopreneurship scientific learning model. The practicalities questionnaire filled by users, i.e.; lecturer and students, to see the extent of the practicality of the model designed.

\section{Discussion}

As mentioned previously, practicality is interpreted as level of usable, easy to use, easy examination and complete with clear instructions. The practicality of this model certainly meets that criteria, aspects tested to the lecturers to see aspects of attracting, developing a process aspect, the aspect of ease of use, functionality and usability aspect and the aspect of reliability. The results showed that the technopreneurship scientific learning model by the lecturers had practical, while the students to see the interest of students, the process of use, increased activity of students in the learning process. Based on the analysis of the practicalities test both lecturers and students gained practical category, it means that this model is easy to use, clear instructions for use and is able to use in the learning process.

Research related to the practice of teaching in the classroom is actually a lot to do with the practicality of a learning model. Production base learning model with nine stages of production as proposed by [1], [2], [3], [4], [5], [6], [7], [8], [9], [10], [11], [12] already conducted trials to see the practicality of this learning model. This implementation is very important in order to provide and help explanation application of learning models for lecturer and students. Vocational education is one of the groups part of science education that prepares graduates to be able to work in their fields and have the ability to survive, so it's impractical the use of this technopreneurship scientific learning model will affect the realization of the purpose of vocational education [24], [20], [19], [13], [14], [15].

The practicality of a learning model will certainly have an impact on the use of the learning process, especially an impact on learning outcomes of students [23], [22], [28], [17]. The practicality of the technopreneurship scientific learning model is very important to be able to conduct the next development phase, if the model is already said to be practical so the researchers could conduct research into the effectiveness phase of this learning model.

\section{Conclusion}

Based on the results and discussions that have been described, there are some conclusions, as follows:

1. The technopreneurship scientific learning model is practically applied to the learning process.

2. The practicality of the technopreneurship scientific learning model suggests that this model is easy to use, clear instructions for use and is able to use in the learning process.

\section{Acknowledgements}

This work was supported in part by Research, Technology, and Higher Education of the Republic of Indonesia, No. 0045/E3/LL/2018.

\section{References}

[1] Ganefri, Hidayat, H., Kusumaningrum, I., \& Mardin, A. (2017a). Needs Analysis of Entrepreneurship Pedagogy of

Technology and Vocational Education with Production Base Learning Approach in Higher Education. International Journal on Advanced Science, 
Engineering and Information Technology, 7(5), 1701-1707.

http://dx.doi.org/10.18517/ijaseit.7.5.1510

[2] Hidayat, H. (2015). Production based learning: An instructional design model in the context of vocational education and training (VET). Procedia-Social and Behavioral Sciences, 204, 206-211.

https://doi.org/10.1016/j.sbspro.2015.08.142

[3] Ganefri., Hidayat, H., Kusumaningrum, I., Dewy, M. S., \& Anori, S. (2017b). Learning Outcomes in Vocational Study: A

Development of Product Based Learning Model. The Social Sciences, 12(5), 831-838.

[4] Hidayat, H. (2017a). How to Implement Technology Science for Entrepreneurship by Using Product-Based Learning Approach and Participatory Action Learning System in Higher Education? Advanced Science Letters, 23(11), 1091810921.

https://doi.org/10.1166/asl.2017.10186

[5] Hidayat, H. (2017b). Impact of Learning with the Production-Based Learning Model in Vocational School. International Journal of Research in Engineering and Social Sciences, 7(2), 1-6. http://indusedu.org/pdfs/IJRESS/IJRESS 1057 92032.pdf

[6] Hidayat, H. (2017c). How is the Application and Design of a ProductBased Entrepreneurship Learning Tools in Higher Vocational Education? Advances in Social Science, Education and

Humanities Research, volume 102, 223228. http://dx.doi.org/10.2991/ictvt17.2017 .38

[7] Hendra Hidayat, S. P. (2017d). Perspektif Pedagogi Entrepreneurship di Pendidikan Tinggi. Prenada Media. https://scholar.google.co.id/scholar?oi=bibs\&c luster=2095749516896821944\&btnI=1\&hl=en

[8] Kusumaningrum, I., \& Ganefri \& Hidayat, H. (2015). Improving Students' Entrepreneurial Interest using Production Based Learning Model in TVET. Advances in Social Science, Education and Humanities Research, 14, 69-

74. http://dx.doi.org/10.2991/ictvet14.2015 .17

[9] Kusumaningrum, I., Hidayat, H., Ganefri, Anori, S. \& Dewy, M.S. (2016). Learning Outcomes in Vocational Education: a Business Plan Development by Production-Based Learning Model Approach. International
Journal of Environmental and Science Education, 11(18), 11917-

11930.http://files.eric.ed.gov/fulltext/EJ11225 58.pdf

[10] Yulastri, A., \& Hidayat, H. (2017). Developing an Entrepreneurship Module by Using Product-Based Learning Approach in Vocational Education. International Journal of Environmental and Science Education, 12(5), 1097-1109. http://files.eric.ed.gov/fulltext/EJ1145587.pdf

[11] Yulastri, A., Hidayat, H., Ganefri, G., Edya, F., \& Islami, S. (2018). Learning outcomes with the application of product based entrepreneurship module in vocational higher education. Jurnal Pendidikan Vokasi, 8(2), 120-131. http://dx.doi.org/10.21831/jpv.v8i2.15310

[12] Hidayat, H., Herawati, S., Hidayati, A., \& Syahmaidi, E. (2018). Pembelajaran Kewirausahaan dengan pendekatan berbasis produksi sebagai alternatif mempersiapkan lulusan berkualitas di pendidikan tinggi. In Prosiding Seminar Nasional Pakar, (pp. 123129).

http://trijurnal.lemlit.trisakti.ac.id/index.php/p akar/article/download/2709/2339

[13] Syahmaidi, E., \& Hidayat, H. (2016). Praktikalitas Perancangan Media e-Learning Berbasis Video. Jurnal Nasional Pendidikan Teknik Informatika (JANAPATI), 5(2), 87-97.

[14] Rahmadani, A. F., Hidayat, H., \& Syahmaidi, E. (2018). Design of Electronic Elementary Material Learning Module on Vocational Higher Education. International Journal of Scientific Research and Management, 6(01). https://www.ijsrm.in/index.php/ijsrm/article/vi ew/1220

[15] Rahmalina, R. (2018). Effect of Use of Mobile Technology and Foreign Culture Against Morale Students. International Journal of Research in Engineering, IT and Social Sciences, 8(7), 265-270. http://www.indusedu.org/pdfs/IJREISS/IJREIS $\underline{\text { S_2105 53722.pdf }}$

[16] Brown, Abbie and Green, Timothy D.2011. The Essentials of Instruction Design Connecting Fundamental Principles with Process and Practice. Second Edition, Pearson Education, Boston,Amerika Serikat.

[17] Crookes, Graham. (2010). The practicality and relevance of second language critical pedagogy. Lang. Teach. 43(3),pp.333-348. doi:10.1017/S0261444809990292 
[18] Borg, W.R, Gall, M.D, \& Gall, J.P. (2003). Educational Research an Introduction. New York: Pearson Education.

[19] Evan, R. N., Edwin, L. H. 1978. Foundation of Vocational Education. Penerbit: Charles E. Merrill Publishing Company. Columbus, Ohio.

[20] Finch, C. dan Crunkilton, J.R. 1984.Curriculum Development in Vocational and Technical Education.Planning, Content and Implementation.Allyn and Bacon, Inc. Boston.

[21] Government regulations of Indonesia Number 32 Year 2013 on National Education Standards

[22] Karumpa, Aco; Parawangsa, Paturungi; Mansyur; \& Saleh, Muhammad. (2016). The Development of Integrative Assessment Model for the Subject of Bahasa Indonesia in Senior High School Students. Journal of Language Teaching and Research, Vol. 7, No. 3, pp. 476483, DOI:

http://dx.doi.org/10.17507/jltr.0703.06

[23] Kember, David \& Kwan, Kam-Por. (2000). Lecturers' approaches to teaching and their relationship to conceptions of good teaching. Instructional Science, 28:pp.469-490

[24] Miller, Melvin D. 1985. Principles and A Philosophy for Vocational Education. Special
Publication Series N. 48.NCRVE. Columbus, Ohio.

[25] Okolocha dan Comfort, Chimezie. 2012. Vocational Technical Education in Nigeria: Challenges and the Way Forward. Journal Business Management Dynamics. Vol.2, No.6, pp.01-08

[26] Prawiradilaga, Dewi Salma. 2008. Learning Design Principles. Publisher: Universitas Negeri Jakarta. Jakarta, Ind.

[27] Sardiman. 2007. Interaction \& Motivation in Teaching and Learning. Publisher: PT. Raja Grafindo Persada. Jakarta, Ind.

[28] Steele, Kassey. (2013). Pre-Service Practicality in Urban Agricultural Education. The Agricultural Education Magazine; Jan/Feb 2013; 85, 4; pg. 19

[29] Suharsimi Arikunto. 2009. Educational Evaluation Basics. Jakarta: Bumi Aksara, Ind.

[30] Undang-Undang Republik Indonesia Number 20 Year 2003. on National Education Standards. Penerbit: BP Citra Jaya. Jakarta.

[31] Widoyoko, Putro., Eko, S. 2013. Research Instrument Preparation Technique.Yogyakarta : Pustaka Pelajar, Ind. 